\title{
Timothy R. Pauketat, An Archaeology of the Cosmos: Rethinking Agency and Religion in Ancient America
}

London and New York: Routledge (2013). Paperback (edition reviewed), 230 pp.; 85 illus., 8 tables. ISBN 9780415521291. £27.99. Hardback, 256 pages. ISBN 9780415521284. £95.00. eBook. ISBN 978020308518-9. £25.19.

\section{Andrew M. Munro}

The University of Oklahoma

Andrew.M.Munro@ou.edu

Timothy Pauketat seeks to integrate anthropology, archaeology and cultural astronomy data to provide fresh insight into the cause-and-effect relationships between the origins of religious belief, changes in such belief through time and the influence of belief on social behaviour. To do so, he makes use of historic-period ethnographic and material culture evidence for Native American people of the Great Plains, as well as a wealth of earlier Mississippian and Hopewell archaeological evidence. This is a dense volume and it is challenging to do it justice in an abbreviated book review.

Chapter 1, "Beliefs", sets forth the principal objective of the volume: to assess how religion influences history and is, in turn, influenced by history. To achieve this, Pauketat investigates the relationship between social agency and the development of religion. A central premise of this work is that the linkages between agency and religion need to be re-thought. Pauketat also proposes that celestial cultural references, as revealed by archaeoastronomy, can provide insight into agency and religion in a prehistoric context. He makes it clear that he does not view prehistoric religions as systems that can be reconstructed in a detailed structural way; rather, he seeks to identify cause-and-effect linkages between religion and historical processes using material culture evidence. This chapter also provides a road-map to the remaining chapters of the book.

The second chapter, "Religion from the Top Down", briefly reviews anthropological theories of religion and then develops a nineteenth-century case study: the religious, political and military movement led by the Shawnee brothers Tecumseh and Tenskwatawa. The multi-tribal movement they headed famously included armed conflict to resist westward expansion by settlers from the United States into Native American lands. Using this case, Pauketat provides a detailed discussion of how agency, including 
agency attributed to observed astronomical events, influenced both religion and history. He also develops the case study to provide an example of how culture creates belief, demonstrating that belief is not "only in the mind" (p. 6). This chapter alone is worth the price of admission: it reveals a complex web of documented historic-period religious and political events that are linked to social agency and observed astronomical phenomena, and it challenges the reader to cross the boundaries of modern academic disciplines.

"Agency" is the theme of Chapter 3, which presents a well-structured discussion on a suggested theoretical approach to move beyond simple models of agency. Pauketat discusses "bundling" and the entanglement of networked elements in a social field - after Ingold's (2006; 2007) "meshworks" model (p. 38) - to achieve better understanding of causative relationships, and Chapter 4, "Bundles", explains how such a networked theoretical approach may yield deeper insight into Native American cultures. This chapter is focused on examination of the cultural uses and influences of Native American ritual objects called "medicine bundles" (p. 42). The concept of bundles is expanded in Chapter 5, "Intimate Parallelisms", to include visual observational astronomy; that is, people's direct visual experiences of the cosmos. This discussion includes published evidence from a variety of Native American cultural contexts in time and place.

Chapter 6, "Religion from the Ground Up", focuses on applying the theoretical constructs from the previous chapters to analyses of material culture evidence for eleventh- to sixteenth-century Mississippian cultures, with an emphasis on the city of Cahokia. The ordered spatial organisation of architecture at Cahokia and other Mississippian sites is assessed and a set of alignment data is presented, including Cahokia's unique "grid" that is curiously offset from true east-west by $5^{\circ}$ (p. 97). Pauketat presents an extensive list of Cahokia-region sites with primary axis orientation data, many of which fit into solstitial and cardinal direction alignment hypotheses. These include the famous multiple phases of construction at Cahokia's "American Woodhenge", as well as an extensive set of mortuary mounds. Pauketat discusses the idea that such alignments and associated ordered design operating at multiple scales are implicitly indicative of bundling and provide evidence of organised religion.

The following Chapter 7, "Bringing Religion to a Standstill", provides data for a set of sites that Pauketat interprets as being associated with the lunar standstill cycle. These include a set of Pffeffer site buildings, some of which he associates with cardinal or solstitial orientations and two groups of which he associates with lunar maximum (major standstill) and lunar minimum (minor standstill) azimuths. The Emerald site, regrettably much reduced by modern earthmoving, is discussed in detail. Pauketat assesses its orientation as associated with the lunar maximum azimuth, and discusses a perpendicular alignment to the Brown Mound, another monumental earthen structure $1550 \mathrm{~m}$ distant. In addition, the chapter includes assessment of three rectilinear structures at the Lange site as being aligned to the lunar minimum azimuth, as well as a set of mortuary sites that include some alignments to lunar minimum. The chapter includes a discussion on the likely associations of Cahokian lunar alignments with similar proposed alignments in the Lower Ohio River valley. It also provides a speculative model for transmission of lunar 
cycle knowledge from the much earlier Hopewell culture, as well as linkage of pilgrimage models in the context of bundling to the architectural forms Pauketat discusses.

In Chapter 8, "Cosmic Deposits", Pauketat continues by considering a range of archaeological and historic-period evidence, in an effort to move beyond simple "cause and effect". He discusses how moving bundles of power and agency can create history as an outcome (p. 164). This chapter provides further evidence to enable understanding of past social structures founded on a relational mesh of bundled entities with agency. It includes detailed discussion of Cahokian mounds, as well as of mortuary trenches at the Mitchell site found to contain female deity sculptures associated with posts, burials and temples that may have been deliberately lunar-cycle aligned. The chapter also discusses historic-period bundles among possible Cahokia descendant tribes involving, for example, types of craft manufacturing being limited to kinship groups that possessed particular medicine bundles. This appears consistent with archaeological evidence from Cahokia for association of some types of craft manufacturing and votive offerings with specific ritual locations, some of which appear to have been deliberately decommissioned using fire. The chapter also provides examples of multi-phased construction and (in some cases) reorientation of buildings Pauketat identifies as "temples", including additional examples where he makes a case for lunar standstill alignments (pp. 170-180). The discussed site histories provide complex examples of multi-stage building, decommissioning, infilling and later excavation. These include one "temple" structure with a "linear depression" on an azimuth of "approximately $53+/$ - 2 degrees" that Pauketat associates with major lunar standstill and one "domicile" with a similar linear depression on an azimuth of $67.0^{\circ}$ that was added after it was dismantled. Pauketat describes the history of this structure as an example of realignment of a "solstitially aligned building" to the "lunar minimum" (p. 178 and fig. 8.12).

Finally, Chapter 9, entitled "Positioning Theory", takes a brief look at how meshed networks of animate and inanimate powers with agency can be related. It provides an ontological framework for deeper understanding of larger-scale histories. This chapter includes a review of how material culture evidence may be applied to improve understanding of agency and prehistoric religion based on recognition of bundling in the material record, as well as movement and change in bundled entities through time and space. The chapter returns to the historic-period example of Tecumseh and Tenskwatawa by discussing a documented case of bundling the prophet's power with a fetish object (a string of beans) that was ritually handled by converts to their movement. This example amply makes the case that efforts to decouple religion from the study of material culture artificially limit our understanding.

This reviewer's primary concerns with the volume are specific to the presented archaeoastronomy evidence. Pauketat himself foreshadows potential objections very early in the text: "Of course, much of what passes as evidence in archaeoastronomy is highly questionable. The best archaeoastronomers - who tend to be professional astronomers (unlike myself) - are the most suspect of such archaeoastronomical evidence" (p. 4). Pauketat does fall prey to an oft-repeated problem in archaeoastronomy interpretation, in that he conflates architectural alignments to the cardinal directions with 
the astronomical concept of equinox (pp. 63-67). This is an all-too common problem in the literature. As Ruggles (1997) has amply demonstrated, the concept of equinox is unlikely to have occurred outside of limited cultural contexts, and cautious testing is required to identify physical evidence for various "pseudo-equinoxes". One of Pauketat's cited sources (Sofaer 2008) similarly conflates orientation to the cardinal directions with equinox at the Chacoan Great House of Pueblo Bonito. It has been demonstrated that there is no operative visual equinox alignment (or visual pseudo-equinox alignment) at that site (Munro and Malville 2010).

Pauketat's presented data to justify the importance of lunar minimums and maximums (a.k.a. "standstills") associated with the "long cycle of the moon" is also reasonably debatable. Thankfully, he explicitly notes that lunar standstill alignment theories remain controversial (p. 74). Regrettably, though, the presented data offers limited potential for resolution of the broader debate. In light of the recent Forum published in Volume 2.1 of the Journal of Skyscape Archaeology, it would be repetitive to discuss the state of lunar standstill theories in detail (see González-García 2016; Malville 2016; Sims 2016). Notwithstanding, a brief critique of the evidence presented in this volume is of value.

An Archaeology of the Cosmos does not include historic-period examples of documented interest in the lunar standstill cycle among likely descendants of the Cahokian people. To bolster his lunar cycle proposals Pauketat cites one supporting source (Sofaer 2008) where multiple proposed lunar standstill architectural alignments at Chaco Canyon (pp. 78-79) have since been demonstrated to be culturally unlikely or statistically insignificant (Malville and Munro 2010). In addition, the alignment data presented does not consistently include precision or degrees of freedom; it does not consistently present associated horizon elevations; it does not include alternative hypotheses for the proposed alignments; it provides no photographic confirmation of proposed alignments; and it does not provide a statistical support case. Pauketat interprets sites using a variety of approaches to propose lunar cycle alignments, including longest-wall azimuths (for example, p. 175), inter-structure azimuths ("rows of mounds, buildings, posts and walls" (p. 153) and the long axes of trenches (pp. 178-179). Throughout, as lunar alignments are discussed he notes that another subset of related sites manifests solstitial or cardinal alignments; however, the full set of proposed alignments is not assessed collectively through space and time. I was disappointed by the limited nature of the presented alignment data and found the lunar cycle argument unconvincing.

The great strength of this volume is Pauketat's theoretical interpretative approach. He demonstrates the utility of defining religion as "ritualized venerations of mystical cosmic powers" (p. 2), as opposed to reducing it to a mental map of orthodoxies and boundaries. Pauketat is explicit that it is not possible to reconstruct prehistoric religious belief systems in any complete way. Nonetheless, through the use of well-documented examples, he convincingly demonstrates the role that naked-eye astronomy can play in networks of entities with agency to create historical actions. He also provides explicit examples of how and why cultural astronomy references may be performative rather than simply predictive. Pauketat provides a useful theoretical approach to integrate archaeoastronomy evidence into broader archaeological data sets. This volume is well worth reading. 


\section{References}

González-García, A.C., 2016. "Lunar Extremes, Lunar Cycles and the Minor Standstill". Journal of Skyscape Archaeology 2 (1): 77-84. https://doi.org/10.1558/jsa.v2i1.30035

Ingold, T., 2006. "Rethinking the Animate, Reanimating Thought". Ethnos 71 (1): 9-20. https://doi. org/10.1080/00141840600603111

Ingold, T., 2007. Lines: A BriefHistory. London and New York: Routledge. https://doi.org/10.4324/9780203961155

Malville. J. M., 2016. "The Enigma of Minor Standstills". Journal of Skyscape Archaeology 2 (1): 85-94. https:// doi.org/10.1558/jsa.v2i1.30213

Malville, J. M. and A. M. Munro, 2010. "Cultural Identity, Continuity, and Astronomy in Chaco Canyon". Archaeoastronomy, the Journal of Astronomy in Culture 23: 62-81.

Munro, A. M. and J. M. Malville, 2010. "Field Methods in Archaeoastronomy with Applications to Chaco Canyon". Journal of Cosmology 9: 2147-2159 [online]. Accessed April 2016, http://journalofcosmology. com/AncientAstronomy115.html

Ruggles, C. L. N., 1997. "Whose Equinox?" Archaeoastronomy: Supplement to Journal for the History of Astronomy 22: S45-S50.

Sims, L., 2016. "What is the Minor Standstill of the Moon?" Journal of Skyscape Archaeology 2 (1): 67-76. https:// doi.org/10.1558/jsa.v2i1.30212

Sofaer, A., 2008. Chaco Astronomy: An Ancient American Cosmology. Santa Fe, NM: Ocean Tree Books. 